\title{
Clarice Lispector's Interviews with Brazilian Jewish Cultural Figures
}

ANNA KATSNELSON

Columbia University

\begin{abstract}
In her public life, Clarice Lispector fought to be recognized as a native Brazilian; however, in her private life, she tended to associate with people with origins like hers. Many of her interviews are with artists who were either children of immigrants or emigrants from Eastern Europe. Scholars have probed Clarice's fiction and the interviews she gave for a view of her approach to Jewish identity, but the interviews she conducted have not yet been examined. This article discusses Clarice's dalliance with identity politics when interviewing notable members of the cultural Brazilian Jewish community, analyzes the questions she asked, and examines how she guided the conversation.
\end{abstract}

Keywords: Homeland, belonging, identity, origin, provenance

While scholars of Clarice Lispector and her Jewish identity have scoured her fictional output and the interviews she gave for clues to her relationship to her ethnic identity, the interviews she conducted have not been examined through a lens that focuses on these issues. Many existing studies analyzing issues of identity in Clarice's work pursue one among multiple paths: tracing the influence of the writer's autobiography, carrying out a textual analysis focusing on philosophical, religious and mystical concepts, or dissecting her literary craft. Furthermore, many critics have analyzed Clarice's work as having or pertaining to a certain Jewish sensibility. Several have claimed a thematization of Jewish markers in Clarice's works. There have been studies by Berta Waldman and Nelson Vieira focused on Macabéa's name (the protagonist of A hora da estrela) as a direct reference to the book of Maccabees from the Hebrew Bible, among others, and discussions of pure and impure foods in A paixão segundo G.H., also 
by Waldman. There have also been a number of critics who have disputed an exclusively Jewish thematic in Clarice's works. Naomi Lindstrom notes that her works display influences of a mixed Judeo-Christian symbolism ("The Pattern" 114). In a different article on the criticism that specifically looks at the Jewish aspects of Clarice's writing Lindstrom shows that even though prevailing critical opinion (as practiced by structuralists, post-structuralists and New Critics) has been against the use of biography, this academic taboo has been bypassed by the cooption of identity politics and an interest in reconsidering writers whose work reflects their status as the 'Other' ("Judaic Traces" 84-85).

Clarice is also often quoted as saying " $\mathrm{Eu}$, enfim, sou brasileira, pronto e ponto" (qtd. in Vieira 117). Still, critics like Hana Wirth-Nesher and Ruth Wisse, writing on Jewish ethnicity and literature, have focused mainly on authors publicly recognized as having participated through their textual subject matters in the creation of their country's hyphenated-literatures. When it comes to Brazilian literature, these authors are often termed Brazilian-Jewish writers. Regina Igel goes further and completely excludes Clarice from her work on Jewish authors in Brazil because of the absence of Jewish themes in her work.

This paper contributes to the work of these scholars by examining the interviews she conducted with other cultural figures with a focus on identity. I provide a look at her association with a Jewish milieu in her role as a journalist and examine her choice of interview subjects and the questions she asked them, as well as her responses to those questions. In her role as an interviewer, Clarice gave ethnically Jewish cultural figures a platform for expressing their relationship to an identity, which in a post-World War II sometimes anti-Semitic Brazil was quite complicated. At the same time her tendency in these interviews is to interrogate her Jewish subjects on their affinity for their Brazilian identity while avoiding any mention, on her part, of their identity or common provenance.

Clarice began publishing interviews in the magazine Vamos Ler! and the newspapers A Noite, Manchete, Fatos \& Fotos: Gente, and Jornal do Brasil. Often Clarice interviewed the most preeminent Brazilians, those who had become just as famous outside of Brazil as inside including: the writer Jorge Amado, the MPB singer and composer Chico Buarque, diplomat, poet and composer Vinícius de Moraes, composer Tom Jobim, architect Oscar Niemeyer, et.al. In her interviews of musicians, artists, and writers Clarice is primarily interested in questions of creativity, love, death, and spirituality. 
When Clarice interviews immigrants, foreigners, or Jewish notables her questions become more open ended, they stray away from specifics. Themes of identity and homeland seem to always come up with these subjects whether she is specifically structuring her questions around these themes or simply by virtue of them being comfortable enough to open up to her. Therefore, her goals for what she wants out of an interview with foreign born and ethnically Jewish interview subjects are different from interviews with natives. While she does not essentialize Jewish identity, she is nevertheless indirectly exploring it.

Clarice interviewed a number of notable personalities with whom she had been acquainted before the interviews and others whom she had wanted to meet through the interviews. This group of culture makers included artist Carlos Scliar, playwright Pedro Bloch, conductor Isaac Karabtchevsky, pianist Jacques Klein, artist Fayga Ostrower, as well as Oscar Ornstein who headed the Hotel Nacional in Rio and Doctor Abraham Ackerman. In interviewing the literary critic Leo Gilson Ribeira, she asked him to talk about his admiration for the Jewish people. In interviewing other notable cultural figures who like her had not been born in Brazil, like Elke Maravilha, Jose Halfin, and Pablo Neruda she asked specifically either about their country of origin or what they considered their homeland to be. This article will show that Clarice, who timidly approached an outright open discussion of her own immigrant identity, was more than happy to provide a setting and a chance for other culture makers of Jewish extraction to talk about their ethnicity, and to discuss origins with other non-native Brazilians.

\section{Questions of Homeland, Identity, and Birth in Clarice's Interviews}

The idea of a native country was quite important to Clarice because she had not been born in Brazil, had experienced the naturalization process first-hand, and knew exactly what it meant to be stateless in the twentieth century. Not only did she repeatedly affirm her brasilidade, but it became a point of departure for her regarding others. In a number of interviews that Clarice conducted in her career as a journalist, she interviewed numerous other successful immigrants and almost always came back to the question of their relationship with their adopted or actual homeland, in other interviews subjects would bring up their brasilidade unprompted by Clarice. 
Questions relating to nationhood and belonging preoccupy Clarice. Her parents had come from the Podolia province of Ukraine (formerly a province in Russia), they had lived in the towns of Teplyk, and then Haysyn (Moser 26). Pinkous and Mania Lispector, and their three daughters, Lea-who would come to be called Elisa, Tania, and Haia (Clarice), received their visas to Brazil in Bucharest, 1922. The youngest of the three, Haia, was born in 1920, when the family stopped in the village of Tchechelnik, Ukraine on their way from the Soviet Union to Brazil. Clarice's naturalization documents from 12 January 1943, list her as being born in Tchechelnik on 10 December 1920 to Pedro and Marieta Lispector (FCRB, CL/Dp 21). The family came to Brazil in 1922, yet Clarice would maintain in all interviews that she was only two months old when she came to Brazil, when in fact she was almost two years old. ${ }^{1}$

Clarice never denied being Jewish, yet she would sometimes deny her place of birth (Moser 10). Clarice's biographer Montero suggests that by denying the origins she was by implication hiding her Jewish ancestry as well (84). Montero feels that references to Clarice's Jewish ancestry bothered her more than being born on Eastern European soil. In most interviews she would deny a Russian provenance not a Ukrainian background, probably because at the time of her birth the Ukraine was losing its wars of independence and would later become a part of the Soviet Union (which Clarice and Brazilian critics who wrote about her typically conflated with Russia).

Clarice was too young to remember the Lispector family's immigration to Brazil - she was less than two years old. She went to great lengths to make a labyrinth of her personal history, yet her inability to remember the journey from the Ukraine to Brazil is credible. Nonetheless, the words that Clarice uses to describe her lack of recall demonstrate her willfulness in distancing her roots, and a subtle, if not outright disdain for the immigrant experience. Clarice writes in a 1971 article for the Jornal do Brasil: "Devem ter viajado de trem da Ucrânia para a Romênia e desta para Hamburgo. Nada sei, recém-nascida que eu era" ( $A$

\footnotetext{
1 "Recebo de vez em quando carta perguntando-me se sou russa ou brasileira, e me rodeiam de mitos. Vou esclarecer de uma vez por todas: não há mistério que justifique mitos, lamento muito. E a história é a seguinte: nasci na Ucrânia, terra de meus pais. Nasci numa aldeia chamada Tchechelnik, que não figura no mapa de tão pequeno e insignificante. Quando minha mãe estava grávida de mim, meus pais já estavam se encaminhando para os Estados Unidos ou Brasil, ainda não haviam decidido: pararam em Tchechelnik para eu nascer, e prosseguiram viagem. Cheguei ao Brasil com apenas dois meses de idade" (A descoberta do mundo 498).
} 
descoberta do mundo 547). Yet she did not travel alone, and Clarice's family members could have filled in the details had she found it worthy of pursuing them when she was old enough to ask.

Considering that Elisa Lispector would write in detail in her memoir No exílio about the experience of immigration, and that Clarice could have asked several family members older than herself for details about the family's experience, "I shall never know" is not a statement of forlorn fact, but an example of Clarice willfully choosing to deny a specific past that could have been rescued. Clarice goes further, when speaking about the trip from Europe. She writes:

A primeira foi com menos de dois meses de idade, da Alemanha (Hamburgo) ao Recife: não sei que meio de transporte meus pais usaram para chegar da Ucrânia, onde nasci, para Hamburgo, onde meu pai procurou emprego mas, felizmente para nós todos, não achou. Nada sei sobre essa viagem de imigrantes: devíamos todos ter a cara dos imigrantes de Lazar Segall. (A descoberta do mundo 545)

A measure of Clarice's reluctance to believe there was anything worth rediscovering in the family experience, rings through in her dismissive comment about her family's affinity to the Jewish immigrants Lasar Segall depicted in his works. At the same time by naming Segall, a modernist painter who immigrated to Brazil in 1923, she is signifying a link between her own experience and that of the Jewish subjects of Segall's paintings. Again, this shows an ambivalence of feeling in regard to her identity; she denies it while at the same time identifying herself with the specifically Jewish 'greenhorns' that Segall is portraying in his painting "The Ship of Immigrants" (1939).

Montero notes that Clarice, like other members of her family, suffered acutely the situation in Europe during the war (84). She also suggests that Clarice was interested in becoming a Brazilian citizen in order to disassociate from the Soviet Union that was in many ways like Nazi Germany. Rather, it seems that Clarice was aware of the threat that an anti-Semitic Vargas government posed to her and a number of other immigrants. She witnessed the trial and sentencing of Olga Benario Prestes and Harry Berger, two European Jews sent back to Germany by the Vargas dictatorship, because of their ties to the Partido 
Comunista do Brasil and their non-Brazilian ethnicity, only to die in concentration camps. It seems that as a result of this threat, during WWII, and fearing deportation that she writes two pleading letters to Getúlio Vargas (president of Brazil at the time) asking him to intercede in granting her Brazilian citizenship (Monteiro 88-90).

In 1942 Clarice began to focus on her naturalization. Although her family members had long ago gone through the naturalization process, she as the youngest waited until she had turned the eligible age to apply for her papers. Prior to marrying Maury Gurgel Valente, who was going to be a diplomat, Clarice needed to have Brazilian citizenship: diplomats could marry only Brazilian citizens. She explained in the letter that she could not read, speak nor write in Russian; her whole family had been naturalized and she was afraid to be sent back to a country whose language was unknown to her. Again, it is important that Clarice stresses the linguistic ties that bind her to Brazil, and that she addresses in her plea to Vargas her attachment to the Portuguese language; the idea of the national language and literature situates and defines her as a Brazilian writer and makes her case for belonging to Brazil better than any pleading about deportation could:

Uma russa de 21 anos de idade e que está no Brasil há 21 anos menos alguns meses. Que não conhece uma só palavra de russo mas que pensa, fala, escreve e age em português, fazendo disso sua profissão e nisso pousando todos os projetos do seu futuro, próximo ou longínquo. Que não tem pai nem mãe —o primeiro, assim como as irmãs da signatária, brasileiro naturalizado - e que por isso não se sente de modo algum presa ao país de onde veio, nem sequer por ouvir relatos sobre ele. Que deseja casar-se com brasileiro e ter filhos brasileiros. Que, se fosse obrigada a voltar à Rússia, lá se sentiria irremediavelmente estrangeira, sem amigos, sem profissão, sem esperanças. (Correspondências 33)

She was naturalized in January of 1943; Brazilian citizenship granted her independence from her history and her immigrant background.

More than just a patriot's adoration of the communicative tool of one's country, the Portuguese language embodied for Clarice the key to her Brazilian 
identity. ${ }^{2}$ Gilles Deleuze and Félix Guattari have posited that a minor literature is created through an author's reinvention of a major language. They list the ways in which writers from a minority group can claim a language, even though they might not be native to the culture of the language. They tie this idea specifically to Kafka's use of the German language:

One way is to artificially enrich this German, to swell it up through all the resources of symbolism, of oneirism, of esoteric sense, of a hidden signifier... Kafka will quickly choose the other way, or, rather, he will invent another way. He will opt for the German language of Prague as it is and in its very poverty. (19)

Unlike Kafka, Clarice changed the Portuguese language. In fact, although she attempted to use an unadulterated Portuguese in her novels, one that was used by her contemporaries, Assis Brasil states that numerous critics accused her works of sounding foreign and alien. It is little wonder then that Clarice refused to be viewed through the prism of her background, or any other distinguishing markers. These reviews heightened Clarice's need to use the language as a weapon to defend her Brazilian identity.

Later in Clarice's life as a writer, she would very often edit the short blurbs about her that editors were keen to publish, or she would send a detailed list of what she preferred they include. Her number one priority was always that she be identified as a Brazilian. In a letter to the editor of the New Mexico Quarterly, Mrs. Carolyn Addir, she writes: “Although I was born while my family was en route to Brazil from Ukraine, I am a Brazilian citizen and my whole upbringing and education were Brazilian. I would be grateful if you stress that fact rather than my birthplace." In a hand-written draft of the same letter she writes, "I have always considered myself Brazilian" (FCRB, CL/CP 089). This is later crossed out and does not appear in the typed version of the letter. There is also a written

\footnotetext{
2 To Clarice, being Brazilian meant above all being able to function in and manipulate the Portuguese language, a signifier of her Brazilian identity. She wrote, "Esta é uma confissão de amor: amo a língua portuguesa" (A descoberta do mundo 134). She campaigned for an identity framed solely in terms of her relationship to this language and went so far as to deny the role of any other language to her identity formation; she wrote, "Eu até queria não ter aprendido outras línguas: só para que a minha abordagem do portugués fosse virgem e límpida" (A descoberta do mundo 135).
} 
description of herself and her biography: "Brazilian writer: married to Maury Gurgel Valente, Brazilian diplomat." The final draft of the letter from January 1957 shows the following addition: "I have always considered myself Brazilian, I am a Brazilian citizen, and the place of my birth is wholly unimportant to me either personally or professionally." It is fascinating that she should write so many drafts of what is essentially very basic biographical information. Yet, it is exactly this attention to biographical detail that shows how attached Clarice was to the idea of her own Brazilianness, and to her created and imaginary identity as nothing but a Brazilian writer.

This stands in stark contrast to Clarice's interview of model and actress Elke Maravilha, where from the beginning of the interview she focuses on the latter's foreignness. Clarice asks Elke:

"Qual é seu nome verdadeiro?

Elke Georgievna Grunupp.

Onde é que você nasceu?

Em Leningrado, 22 de fevereiro de 1945.

Onde se criou?

Em Minas Gerais...." (Clarice na cabeceira 208)

Even though in interviews conducted with Clarice she runs away from questions of birth and foreignness, when she interviews others she is specifically drawn to the subjects that she least of all likes discussing: like Elke's country of origin, Russian patronymic, and last name. ${ }^{3}$

How does Clarice approach the issue of her immigrant identity? The questions Clarice asked her interviewees, especially those who were also immigrants, and the themes she picks with a focus on country of origin versus one's adopted nation, help shed a light on her relationship to her own immigration history and her understanding of homeland as a place other than one's land of birth. In an interview with Jose Halfin, an Air France executive who was born in Romania, she asks: "Uma resposta franca: o Brasil é a sua pátria ou sua segunda

\footnotetext{
${ }^{3}$ In one of her chronicles, she refers to a conversation with one of her sons during which she denied delving into her private life, "Um de meus filhos me diz: porque é que você, ás vezes escreve sobre assuntos pessoais? Respondi-lhe que, em primeiro lugar, nunca toquei, realmente, em meus assuntos pessoais, sou até uma pessoa muito secreta" (A descoberta do mundo 435).
} 
pátria?" (FCRB, CL04F 01-05). ${ }^{4}$ Halfin, like herself, is an immigrant, and therefore she looks for more insight into her own attachment to Brazil in the responses of other immigrants.

In an interview with Doctor Abraham Akerman, Clarice avoids nationality. Following the model of the artist and writer interviews, Clarice asks Akerman about his love for his calling - medicine, but perhaps sensing that with Clarice he can discuss Jewishness, he also brings up their shared ethnicity. Clarice asks him about death; his response is singular:

Meu querido pãe era desde jovem: spinozista. Como você deve saber, Spinoza era um jovem filósofo que vivia em Amsterdã e foi excomungado publicamente pela sinagoga. Minha filosofia é a dele. Quero, além disso, declarar que só existem na realidade três minorias oprimidas: o negro, o judeu, e a mulher. (FCRB, CL04F $39-42)$

Akerman assumes that she is just as aware of Jewish philosophy as he is; in fact, Clarice had been an avid reader of Spinoza. She owned a copy of Spinoza's writings in French, and her first novel, Perto do coração selvagem, mentions Spinoza's philosophy on several occasions (Moser 109). Yet, again, just as in previous interviews Clarice does not respond to this provocation that would lead her to enter into a discussion of Spinoza and changes the subject. She turns the conversation to Akerman's love for Brazil. He says, "Quem não gosta do Brasil é um burro" (FCRB, CL04F 39-42). Her questions reinforce her preoccupation with an exile that allows one to embrace the new "patria," in her case Brazil. If her interviewees stray from the questions she poses and bring up their shared Jewish identity, she follows up with a question that can only demonstrate that for her the only identity worth mentioning is Brazilian.

When Clarice interviews non-Brazilians like the Chilean poet Pablo Neruda, she keeps circling back to questions of identity and native land. One can see that this is a natural preoccupation for her. She asks him: "Você se considera mais um poeta chileno ou da América Latina?" He answers: "Poeta local do Chile,

\footnotetext{
${ }^{4}$ The interviews archived at FCRB, almost as a rule do not have dates of publication and do not list the title of publication. This is also the case with many interviews published in Entrevistas, and Claire Williams discusses this in her introduction to the volume.
} 
provinciano da America Latina" (Lispector, Entrevistas 72). She does not ask the native Brazilian culture makers she interviews if they feel themselves to be Brazilian, her major themes are art and love, but with other foreigners, or naturalized Brazilians, this is a subject matter that she highlights throughout her interviews. She asks Neruda: "Em que lugar gostaria de viver se não vivesse no Chile?" (Entrevistas 72). It seems evident then that Clarice is often preoccupied with questions of birth. These are questions which she must have asked herself a thousand times, and in Neruda's love for Chile she finds her own love for Brazil reflected. Neruda answers with a few lines from his own poem "Se tivesse que nascer mil vezes. / Ali quero nascer. / Se tivesse que morrer mil vezes. / Ali quero morrer..." (Lispector, Entrevistas 72-73). Yet again, Clarice's questions show that one of her chief considerations is always an interest in how her subjects feel towards their homelands, whether adopted or natural. Would they choose to remain there, would they choose to leave? This reinforces her own love for Brazil, which she reiterates over and over is her chosen patria.

Clarice is a reader of Neruda's poetry, she has known before the interview that his love for Chile is supreme, and therefore she guides him with her questions to give a response that is similar to her own feelings about Brazil. Even though she was not born in Brazil, it seems fair to say that she envied her Brazilian friends their natural belonging to Brazil. Neruda's words about Chile exemplify her own longing to have been born in Brazil, and her wish to be buried nowhere else but in Brazil. When outside of Brazil, she dreamed of returning. She was in love with the country, its culture and its landscape. ${ }^{5}$

When Clarice interviews the poet Ferreira Gullar, who was exiled by the Brazilian dictatorship from 1965-1977, Clarice asks him about exile, where he lived, how he survived, but even here, where a question of how he feels towards his native land would feel natural, she does not ask how he feels about Brazil or his Brazilian identity. She asks instead if he's been back to Maranhão his "terra natal" since returning from exile. Gullar responds that he has not and that it is complicated. Clarice says that his Poema sujo reminded her of Recife, "que é a minha terra" (Entrevistas 52). This seems to reveal again that with anyone who

\footnotetext{
${ }^{5}$ In Europe where he husband was on a diplomatic posting she said to a friend, "I'm dying of longing for home and for Brazil...This isn't traveling: traveling is leaving and going home whenever you want to, traveling is being able to move. But traveling this way is awful: it's serving out sentences in different places" (Moser 160).
} 
is either non-native Brazilian or exiled like Gullar, she cannot help but think about her own fraught relationship with her adopted homeland.

Lilian Hack argues that in interviews of visual artists, Clarice keeps to three major themes about which she asks specific questions such as: when did they begin to practice their art, do they feel that it is their true calling, and specific questions relating to the classification of the genre in which they work. When interviewing writers and poets: Lygia Fagundes Telles, Rubem Braga, Jorge Amado, Nelson Rodrigues, Fernando Sabino, Érico Verissimo, Nélida Piñon, Ferreira Gullar, Millôr Fernandes, Hélio Pellegrino, Antônio Callado, Marly de Oliveira, José Carlos Oliveira, and Alceu Amoroso Lima, Clarice's questions vary only slightly; most of them ask about process, inspiration, and the act of creation (Entrevistas). She also asks at least a third of these interviewees about love, and another third about death. Questions of Brazil as a homeland come up in none of these interviews with native Brazilians.

\section{Venue and Platform}

Clarice worked with several people from the same Russian-Jewish upbringing in the publishing and print media. Already in the 1950s, Clarice began to have trouble finding work. Paulo Francis, one of the few who noticed how she was struggling at this time, wrote after her death that in 1959, along with Nahum Sirotsky and Carlos Scliar, he helped get her work at the magazine Senhor, with the sponsorship of Simão and Sergio Waissman, who owned the magazine. Her friends arranged for her to write new material for a Jewish-owned publication. Montero also notes that the publication Senhor was extremely important to Clarice's survival at this time, and that Sirotsky wrote her an invitation letter to begin writing for the magazine (200). The magazine Senhor led to Clarice's fame as a writer of short stories, and it provided a platform for subsequent publication.

The most ironic personal detail from Clarice's life, juxtaposing her affiliation with leading Jewish intellectuals and her larger assimilation as a Brazilian, was her dismissal from the Jornal do Brasil. In 1973, Clarice lost her job at Jornal do Brasil, as did all the Jews who worked there, including its editor/director Alberto Dines, a journalist and biographer who later wrote a work about Stefan Zweig. Dines published Clarice's works at Jornal do Brasil from 1967 to 1973; in December of 1973, Dines himself was fired. Montero writes that Dines was 
accused of mismanagement. Yet, in fact, political machinations when the President of Petrobras Ernesto Geisel became the President of Brazil and took the side of the Arabs after the Yom Kippur War led to a number of Jews being fired from key positions (Montero 263). After being terminated, Clarice's financial situation became quite dire and she turned to translations to support herself.

Lesser writes that by the 1970s, the Brazilian government returned to using rhetoric that was decidedly anti-Jewish, a fact that reverberates with the events that occurred to Clarice and her Jewish colleagues (173). For the first time in her life, Clarice became affected by anti-Semitism in Brazil. Although this had already been apparent to many of her contemporaries, she was not aware of it until she personally suffered from it. Montero considers her dismissal from the Jornal do Brasil to be a turning point in her life, when Clarice came to terms with and embraced her Jewish identity (263). Montero writes that Clarice enjoyed the comparison Dines made between her and Kafka but never wanted to reveal her whole self to the public, which in the biographer's opinion is possibly why she was not interested in using Jewish elements in her texts. At the same time, an absence of almost all signifiers, of almost all markers of "Jewishness" in her texts (in "Onde estivestes da noite" there is one character called "o judeu"), are a sign that she felt such elements to be dangerous to her individuality and to her status as a purely Brazilian writer.

In an interview with Carlos Scliar, a close friend of hers, at whose house in Cabo Frio she passed many weekends, again Clarice does not ask anything personal, or suggest that they are children of immigrants and of the same provenance. She does talk in the preface about how long they have been friends, and how much she likes and admires him: "Há muito tempo eu não vi Scliaracho que desde o tempo áureo da revista Senhor - de modo que os primeiros momentos de nosso encontro foram gastos em efusões mútuas de amizade. Eu simplesmente gosto de Scliar.... Conheço Scliar há muito tempo" (Entrevistas 167). The attentive reader would have to know that Scliar helped Clarice get a job at Senhor, and she refers to the golden time there wistfully. When Clarice was deciding to publish a novel she then called Objeto gritante (the title would later be changed to Água viva), she went to Scliar's house to discuss this important moment in her life (Montero 259). According to Montero, Clarice was at home in this circle of friends, and the biographer stresses it was these friends 
who transformed a part of Brazil into a shtetl, though the meaning of this comment is vague. Did they drink tea and discuss Russian literature and share jokes, or is it simply that they had a similar way of looking at Brazilian life from the vantage point of their shared Eastern European Jewish heritage?

In the interview with Pedro Bloch, Clarice lets the readers of her interviews learn that the Blochs are also her friends. In the preface to the interview, she makes this evident by describing Miriam, Bloch's wife: "Fui convidada pela doce Miriam Bloch para almoçar na casa agradibilissima deles, aceitei contente. E entrevisto Pedro, uma das pessoas mais entrevistáveis que eu conheço" (Entrevistas 86). This suggests to the reader that Clarice is well acquainted with the Blochs: she knows that Miriam is sweet, has been to the pleasant apartment before, and loves listening to Bloch, these are all the reasons for her acceptance of the lunch invitation. Her knowledge of the family relations and her connection and admiration for this family team who are close friends is also visible in her line of questioning, as she asks Pedro to talk about his wife: "Miriam é a sua companheira ideal, são pássaros do mesmo ninho. Em que mais, além do grande amor, essa criatura acompanha você?" (90). These are questions that one can ask only of close friends whom one has examined for years. It is evident that Clarice regards the Blochs as if they were her own extended family members.

Bloch was the nephew of Adolpho Bloch, the founder of Manchete, a paper that also employed Clarice. In fact, the interviews shed a light on the cultural Jewish community of which Clarice was a part. When she interviews Karabtchevsky, at the time the assistant director of the Orquestra Sinfônica Brasileira, (there is an interesting omission: she does not interview the director of the OSB, who at the time was Alceo Bocchino), he begins to talk about his relationship with Adolpho Bloch. It seems that Karabtchevsky knows that Clarice will be interested in his relationship with Bloch, the man who has employed her. She asks him to talk about how he feels when he conducts, he gives a twosentence response, and launches into a story that he believes will be more interesting for both of them. He tells the story of how he approached Adolpho Bloch with the goal of bringing symphonic music to marginalized communities. Bloch then organized a performance of Tchaikovsky's 1812 Overture at the Monumento dos Pracinhas, with OSB and three military bands: 
Nos acordes finais da 1812, onde o Hino Russo se impõe, vi o povo correr em minha direção. Na frente de todos, de braços abertos, quase chorando, vinha Adolpho. Senti que havia ganho nesta noite um grande amigo. E não só isso: em diferentes etapas de minha vida, foi Adolpho o conselheiro, pai e irmão. (Lispector, Entrevistas 125)

Again, what is interesting about this interview with Karabtchevsky is that even when Clarice asks few leading questions, the memory and cognizance of their shared background allows the conductor to bring up a common acquaintance as a subject of discussion. Similarly, when Clarice interviews the pianist Jacques Klein, he mentions that he has worked with Karabtchevsky: "Adorei tocar em Israel, sob a regência de Isaac Karabtchevsky" (Lispector, Entrevistas 129).

In her interviews, Clarice hints at the existence of a greater cultural Jewish community, where members exist not in a vacuum but in knowledge of each other and the work they are producing. For example, when she interviews Carlos Scliar, she mentions having interviewed Fayga Ostrower, and they talk about her (Entrevistas 171). Karabtchevsky brings up Adolfo Bloch in his interview, while Jacques Klein brings up Karabtchevsky. Both the interviewer and the interviewee highlight what they think will interest the other.

\section{Interviews that Discuss Israel}

Elisa, who was also a novelist, albeit not as famous as her youngest sister, was acutely aware of a longing for the Jewish homeland. Her semi-autobiographical novel is aptly titled No exílio (1948), and it begins with the proclamation of the foundation of Israel. Unlike her sister, though, Clarice does not embrace a homeland outside of Brazil; she rejects the Ukrainian homeland, which forced the family to become refugees in Brazil, and never mentions Elisa's chosen homeland in any of her writing. In fact, Clarice would go so far as to ask her sister to not re-publish No exílio once it had become a success. Montero notes: "Elisa decidiu reeditar No exílio pelo editor Ebrasa, em convênio com INL. A publicação foi feita em 1971. Clarice não achou uma boa idéia a reedição desse livro" (256). In an interview granted to Igel, Elisa commented on the text's similarity to her real life: 
O Exílio tem muito de autobiográfico e de minha ligação com meus ancestrais. Ele representou, para mim, uma forma de liberação. Precisei expor as angústias, as tristezas, o terror de uma menina que viu os pogroms, os assaltos da multidão e a destruição sistemática de sua casa e as de outros judeus lá na Rússia. Aquela menina que não entendia nada daquilo ficou dentro de mim. A tristeza me acompanhou durante todo o fazer do livro, mas terminei-o num dia alegre para nós, quando foi aprovada pela ONU a criação de Israel. (184)

The distance between the sisters regarding family history, and more specifically their Jewishness, could not be wider. Elisa uses exile as the agency through which to liberate herself, and, furthermore, notes that she still carries within her "that girl who could not understand." For Elisa, No exílio creates a link between her personal liberation from the traumatic history of pogroms and exile to the creation of Israel. In this she diverges from the Clarice who dismisses any attempt to recreate the family experience. Lindstrom writes that Clarice's stifled Jewishness "is manifested with a vengeance in No exílio" "“Clarice Lispector and Elisa Lispector" 58).

To create an exclusively Brazilian identity, one that barred all other influences while Europe was in turmoil, could be seen as a matter of selfpreservation. To continue maintaining her brasilidade after World War II suggests that Clarice was constantly involved in the process of legitimizing her Brazilian self, yet it is obvious from her interviews that the subject of belonging never ceased to interest her and determine her own relationship to her immigrant background. Although Clarice herself never discussed Israel as being important to her, she chose to interview subjects who like her sister Elisa valued the creation of the state of Israel and were able to articulate its importance to the wider Brazilian audience, which read Clarice's interviews.

In interviewing another immigrant from Europe, Oscar Ornstein (hotelier, and music and theater producer) Clarice asks him an open-ended question, inviting him to speak about anything that is important to him: "Você têm alguma coisa a declarar?" This question leads to Ornstein's lengthy discussion about being an immigrant whose family perished in Auschwitz, and who was saved by 
being allowed to come to Brazil. He brings the conversation back to their common denominators: immigration and brasilidade:

Sou um homem de 65 anos, comecei minha vida no Brasil como imigrante ... Segundo dizem, sou um bom brasileiro porque assim o quis. Alias, o saudoso deputado Emilio Carlos disse uma vez da tribuna da Câmara quando um colega chamou um presidente do Banco do Brasil de não ser brasileiro: 'não há brasileiros; o que há são uns que chegaram mais cedo e outros mais tarde.' (FCRB, CL04f 25-28)

His responses always draw attention to both his Brazilian identity and his interest in world Jewry. It is almost as if Ornstein wishes to highlight that one can be both Brazilian and Jewish. Clarice asks about the important people he has met. $\mathrm{He}$ names Ben Gurion, Prime Minister of Israel. Clarice then enquires about the notables he wants to meet. Her questions are not-specific to identity, yet he chooses to name Saul Bellow, the Canadian-American Jewish novelist who received the Nobel Prize in Literature in 1976. Later she asks a general question about his politics and he answers that Israeli politics interest him and he wishes for peace in the Middle East. None of Ornstein's responses, which pinpoint a shared ethnicity, elicit further probing questions from Clarice. For example, she does seem surprised that Ornstein chooses to speak about a Canadian American writer instead of one closer to home. In fact, it seems as if she wants to move the interview forward to increase the distance between herself and Jewish culture or adherents to it, yet by having chosen Jewish subjects to interview and asking vague questions she lets them choose what is important.

This reticence with her Jewish subjects is mirrored by her rarely discussing politics with her interview subjects. This might be because many of the interviews are from 1968-1977, when Brazil was ruled by a military dictatorship, and it would have been difficult to speak openly about politics. She asks Chico Buarque about participating in the Passeata dos Cem Mil student protests on 26 June 1968, and he responds by saying that he also saw her there. She responds: "Fui pelos mesmos motivos que você. Mudando de assunto, Chico, voce já experimentou sentir-se em solidão?" (Entrevistas 103). It seems that Buarque and Clarice are on the verge of having a subversive and interesting conversation 
about Brazilian politics. As with her Jewish subjects, when the conversation comes too close to a discussion of politics, Clarice moves to a safer subject.

Clarice, by virtue of her Jewish identity, provides her subjects with a safe space where they can speak about their background and ethnicity without fear of prejudice or judgment. During her interview with Karabtchevsky, Clarice asks when he first began to conduct, he tells about his early childhood, she presses him to talk about his education as a conductor, but he turns the dialogue to tell of his interest in becoming a Zionist and going to a kibbutz:

Com dezesette anos resolvi ser sincero com meus convicções e tornar me um sionista-e mais especificamente, um sionista no kibbutz em Israel, forma de grandes cooperativas, onde não existe a propriedade individual, tudo é dividido irmamente e onde eu tinha dois irmãos trabalhando e vivendo. (Lispector, Entrevistas 123-24)

This is an example of Clarice allowing the cultural luminary to become so comfortable with her that instead of directly answering her question he speaks about his own international background, educates Brazilian readers on Israel, and on the ideas of socialism and social justice that he admired while living on a kibbutz: the divided property, the lack of inequality, etc. In other words, Clarice might not probe deeply into the motivations of her subjects, but her curiosity and interest in the greater Brazilian Jewish community allow her to use her platform to bring in diverse voices, that do not reflect majoritarian Brazilian values, and to give them a small megaphone.

\section{Other Interviews on Identity}

In her interview with the famous literary critic Leo Gilson Ribeiro, who was not Jewish, Clarice brings up Yiddish author Isaac Bashevis Singer. Once the subject of Jewish literature is introduced, Clarice asks: "Você me disse uma vez que tem obsessão pelos judeus. O que quer dizer isso?” (FCRB, CL04F 55-57) Time and time again in these interviews, instead of talking about Jewishness herself, Clarice the journalist serves as an anxious medium for others to speak of Jews and their accomplishments. Ribeiro responds: 
No plano da admiração, quase sem reservas, tenho mesma obsessão pela inteligência dos judeus, pela sensibilidade e contribuição que eles apresentaram a todos os ramos do conhecemento humano. Citando: Hannah Arendt, Freud, Marx, Einstein, Martin Buber, Rosa Luxembourg, Isaac Stern, Arthur Rubinstein, Vladimir Horowitz, etc. Na literature você sente a marca de Kafka, Proust, e da propria Biblia....Mas o fato é que numericamente, os judeus têm um superávit de inteligênciatalvez porque são uma minoria e os goim a maioria. E depois, Jesus também era judeu.... (FCRB, CL04F 55-57)

Clarice herself brings up the topic of Ribeiro's admiration for Jewish culture, yet in all her interviews, this is possibly the only time that she does this, and in fact she chooses a non-Jew to speak about the accomplishments of Jews. She feels that the subject is safe only when it is interpreted by someone whom the mainstream will consider impartial. At this point, Clarice changes the topic to philosophy, pointing out once again that anything too connected to her own circumstances makes her uncomfortable (FCRB, CL04F 55-57).

The question then must not be why Clarice denied being Russian or Ukrainian, as her natural aversion to these countries has already been explained. Rather, the question is why so many friends at her funeral were shocked that she was Jewish (Lerner 49). She had consciously removed every reference to her parents' religion and culture from her work. References to knowledge of Yiddish as well as intimate details of her relationship with her immigrant family are not to be found in her writings. At the same time, her interviews of other immigrants and Jews or people who were interested in Jewish topics shows Clarice's subtle interest in the Brazilian Jewish community, in reveling in their success in Brazil, and in having them talk about issues dealing with identity, which she usually stayed away from. Luis Correa de Araujo writes about Clarice thus: "Clarice Lispector teria sido no Brasil a primeira escritora a perceber a vacuidade das biografias, a contestar em seus textos a validade (e a comodidade) de uma narração consistente, a emancipar o autor da sua identidade e experiência." At the same time, I have tried to show here that Clarice succeeded in examining her identity through her interview subjects. 


\section{Conclusion}

In his essay, "Reflections on Exile," Edward Said writes: "Exile is predicated on the existence of, love for, and bond with, one's native place; what is true of all exile is not that home and love of home are lost, but that loss is inherent in the very existence of both" (185). Said's vision of exile as loss that is essentially bound to the nature of existence suggests exile as a means of agency for the immigrant writers Clarice and her sister Elisa. Said continues: "It is not surprising that so many exiles seem to be novelists [...] and intellectuals" (181). Though Said's definition of exile falls short of embracing Clarice's very peculiar, but ever-present, exilic tension, exilic subjects can also jealously insist on a right to belong to the homeland that adopted them. The level of zealous devotion that Clarice exhibited in her love for Brazil is, in fact, another form of the exilic longing to belong. The search for belonging within an adopted homeland is as intrinsically a characteristic of exilic writers as not belonging.

\section{Works Cited}

Brasil, Assis. "Mundo subjetivo de Clarice Lispector." Jornal do Brasil, 3 Dec. 1960, pp. 325-26.

Correa de Araujo, Luís. "Moldura e mágica da palavra.” Minas Gerais, vol. 640, set. 1969 , p. 6.

Deleuze, Gilles, and Félix Guattari. Kafka: Toward a Minor Literature. Translated by Dana Polan, U of Minnesota P, 1986.

Francis, Paulo. "Clarice: impressões de uma mulher que lutou sozinha." Folha de São Paulo, 15 Dec. 1977.

Fundação Casa de Rui Barbosa (FCRB), Rio de Janeiro, Brazil.

Hack, Lilian. "Clarice Lispector e as entrevistas com artistas: uma escuta da pintura." Revista Valise, vol. 7, no. 14, 2017, pp. 70-89.

Igel, Regina. Imigrantes judeus/escritores brasileiros: o componente judaico na literatura brasileira. Perspectiva, 1997.

Lerner, Julio. Clarice Lispector, essa desconhecida. Via Lettera, 2007.

Lesser, Jeffrey. Welcoming the Undesirables: Brazil and the Jewish Question. U of California P, 1995. 
Lima, Alceu A., and Claire Williams, editors. Clarice Lispector: Entrevistas. Rocco, 2007.

Lindstrom, Naomi. "Clarice Lispector and Elisa Lispector." Modern Jewish Studies, vol. 12, no. 4, 2001, pp. 58-64.

-. "Judaic Traces in the Narratives of Clarice Lispector: Identity Politics and Evidence." Latin American Cultural Production, edited by David William Foster, Vanderbilt UP, 2009, pp. 83-96.

-. "The Pattern of Allusions in Clarice Lispector." Luso-Brazilian Review, vol. 36, no. 1, 1999, pp. 111-21.

Lispector, Clarice. A descoberta do mundo. Nova Fronteira, 1984.

—. A hora da estrela. José Olympio, 1977.

—. A paixão segundo G.H. José Olympio, 1977.

—. Água viva. Arte Nova, 1973.

—. Discovering the World. Translated by Giovanni Pontierro, Carconet, 1992.

—. Minhas queridas. Rocco, 2007.

Lispector, Elisa. No exílio: romance. Irmãos Pongetti, 1948.

Montero Ferreira, Teresa Cristina. Clarice Lispector: correspondências. Rocco, 2002.

—. Eu sou uma pergunta: uma biografia de Clarice Lispector. Rocco, 1999.

Moser, Benjamin. Why This World: A Biography of Clarice Lispector. Oxford UP, 2009.

Said, Edward W. Reflections on Exile and Other Essays. Harvard UP, 2000.

Vieira, Nelson H. Jewish Voices in Brazilian Literature: A Prophetic Discourse of Alterity. UP of Florida, 1995.

Waldman, Berta. Entre passos e rastros: presença judaica na literatura brasileira contemporânea. Perspectiva, 2002.

Williams, Claire. "Prefácio: Clarice 'Entre-vistas."' Clarice Lispector: Entrevistas, edited by Alceu A. Lima and Claire Williams. Rocco, 2007, pp. 7-12.

Wirth-Nesher, Hana. "Defining the Indefinable: What is Jewish Literature." What is Jewish Literature?, edited by Hana Wirth-Nesher, Jewish Publication Society, 1994, pp. 3-12.

Wisse, Ruth R. The Modern Jewish Canon: A Journey Through Language and Culture. Free P, 2000. 